\title{
PLURALISME HUKUM DI INDONESIA
}

\author{
Angga Saputra \\ Email: 2010003600207@unespadang.ac.id \\ No BP: 2010003600207 \\ Fakultas Hukum Universitas Eka Sakti Padang
}

\section{A. PENDAHULUAN}

Indonesia, salah satu negara yang terkenal dengan jumlah penduduk muslim terbesar di dunia dengan keragaman etnis, agama, dan suku bangsa, telah memilih sistem hukum campuran. Hal ini memberi peluang kepada sumber hukum tertentu mempengaruhi pembentukan dan penyusunan norma-norma hukum nasional. Hukum Islam yang telah lama digunakan dalam masyarakat, bahkan sebelum masa kolonial, telah memberikan pengaruh nyata dalam hukum adat tertentu di masyarakat.

Istilah pluralisme hukum secara luas digunakan sejak awal abad 20, dalam banyak kasus berpotensi ditafsirkan dan diterapkan secara berbeda. Sebagai suatu konsep akademik, pengertian pluralisme hukum terus berubah dan terus dipertajam. Perkembangan terkini adalah pendekatan pluralisme hukum dalam prespektif global, memandang pendekatan lama sudah tidak memadai lagi.

Karakteristik pluralisme juga terjadi dalam domain hukum. Selama berabad-abad, sistem hukum Islam, sistem hukum Adat dan sistem hukum Barat telah mempengaruhi bangunan sistem hukum di Indonesia. Ketiga sistem hukum tersebut, telah mempengaruhi dan mengubah sistem hukum yang lebih plural sepanjang waktu hingga sekarang ini. Bahkan keserasian penggunaan hukum Islam dan hukum Adat dalam peradilan pernah dipraktikan secara nyata Bahkan dalam isu otonomi daerah (pasca reformasi) penerapan syariah Islam di tingkat daerah (kota dan/ kabupaten) turut mewarnai pembentukan peraturan tingkat daerah

Salah satu contoh konflik hukum yang nyata dan sekaligus contoh yang berulang dikemukakan adalah konflik hukum adat dan hukum negara. Undang-undang No. 5 Tahun 1960 (UU Pokok Agraria) dengan jelas memberikan pengakuan terhadap hak masyarakat hukum adat dalam penguasaan tanah dan SDA, tetapi masih ada regulasi lain yang menegasikan prinsip tersebut, UU Kehutanan (UU No. 41 Tahun 1999) misalnya yang mengakui keberadaan hutan adat, akan tetapi 
UU tersebut menempatkan hutan adat sebagai bagian dari hutan negara. Konflik sistem hukum tersebut tidak jarang berujung pada konflik horizontal maupun vertikal dan menggambarkan bahwa sesungguhnya terdapat gap atau kesenjangan antara pembentuk hukum (institusi negara) dengan pengemban hukum (masyarakat).

Hal ini seolah menegaskan bahwa munculnya penolakan terhadap hukum negara bukan sekedar persoalan keterbatasan pemahaman atau ketidaksadaran hukum masyarakat, tetapi lebih dari itu adalah karena ketidaksediaan rakyat menaati hukum yang berbeda dengan keseharian mereka.

Beranjak dari kondisi tersebut, muncul pertanyaan apakah yang dapat dilakukan untuk mendamaikan kedua hukum tersebut atau setidaknya mempersempit kesenjangan diantara kedua hukum itu. Menjawab pertanyaan tersebut, berbagai upaya telah dilakukan bahkan sejak masa kolonial, secara substansi hukum negara mengakui keragaman hukum yang hidup dalam keseharian masyarakat, dan secara strategi pembangunan hukum, negara harus menitikberatkan pengenalan hukum pada masyarakat ketimbang memaksakan keberlakuan hukum negara tersebut. Dalam konteks ini lah, pendekatan pluralisme hukum dalam pembentukan hukum nasional dan pengenalan hukum menjadi amat penting.

\section{B. PEMBAHASAN}

Pluralisme hukum di Indonesia adalah pemahaman mengenai keberadaan mekanisme-mekanisme hukum yang berbeda yang ada di masyarakat di Indonesia. Pluralisme hukum di Indonesia ini berupa hukum Keperdataan, hukum Pidana, hukum Adat, hukum Tata Negara, hukum Administrasi Negara, hukum Internasional serta hukum-hukum lainnya. Secara sederhana, pluralisme hukum hadir sebagai kritikan terhadap sentralisme dan positivisme dalam penerapan hukum kepada rakyat. 
Pluralisme hukum muncul disaat berkembangnya pemikiran para ahli antropolog bahwa sentralisme hukum (hukum negara) bukan satu-satu nya hukum yang mengatur kehidupan masyarakat. Karena pemberlakuan sentralisme hukum dalam suatu komunitas masyarakat yang memiliki kemajemukan sosial dan budaya hanya merupakan sebuah kemustahilan (Griffiths). Pluralisme hukum juga muncul di Indonesia karena adanya kemajemukan budaya. Itu dibuktikan dengan adanya semboyan "Bhineka Tunggal Ika, yaitu berbeda-beda tapi tetap satu". berbeda dalam cakupan ini meliputi, ras, etnik, suku, agama, budaya, dan sebagainya adalah yang menjadi bukti dari kemajemukan budaya. Keragaman ini lah yang menghimpun menjadi kesatuan bangsa Indonesia dan dilindungi dalam naungan Negara Kesatuan Republik Indonesia. Dalam keberagaman ini, pasti memunculkan potensi konflik, atas pemikiran atau pandangan yang berbeda-beda dari masyarakat Indonesia, maka di munculkan lah suatu istilah bernama hukum untuk memberikan arahan perilaku masyarakat

Isu maupun kajian seputar pluralisme hukum bukan isu baru ataupun ranah studi baru di Indonesia. Secara sederhana, pluralisme hukum hadir sebagai kritikan terhadap sentralisme dan positivisme dalam penerapan hukum kepada rakyat. Terdapat beberapa jalan dalam memahami pluralisme hukum. Pertama, pluralisme hukum menjelaskan relasi berbagai sistem hukum yang bekerja dalam masyarakat. Kedua, pluralisme hukum memetakan berbagai hukum yang ada dalam suatu bidang sosial. Ketiga, menjelaskan relasi, adaptasi, dan kompetisi antar sistem hukum. Keempat, pluralisme hukum memperlihatkan pilihan warga memanfaatkan hukum tertentu ketika berkonflik.

Dari tiga cara pandang tersebut dan masih banyak cara pandang lainnya, secara ringkas kita bisa katakan bahwa pluralisme hukum adalah kenyataan dalam kehidupan masyarakat. Senada dengan itu, meminjam ungkapan dari Brian Z. Tamanaha, legal pluralism is everywhere. Ungkapan ini menegaskan bahwasanya di area sosial keragaman sistem normatif adalah keniscayaan. Namun, hal menarik tentang pluralisme hukum bukan hanya terletak pada keanekaragaman sistem normatif tersebut, melainkan pada fakta dan potensi untuk saling 
bersitegang hingga menciptakan ketidakpastian. Ketidakpastian ini menjadi salah satu titik lemah dari pluralisme hukum, walaupun hal ini tidak sepenuhnya benar karena permasalahan pokok dari potensi konflik tersebut adalah adanya relasi yang asimetris dari sistem normatif tersebut.

Secara akademik, pluralisme hukum adalah bagian dari kajian antropologi hukum. Hukum dalam kajian antropologi mengandung konsep normatif dan kognitif untuk menjelaskan keragaman hukum yang satu sama lainnya memiliki sistem (cluster) hukum berbeda.7 Atas dasar itulah hukum dipandang sebagai hasil interaksi sosial terkait oleh unsur-unsur kebudayaan dalam arti luas, meliputi politik, ekonomi, ideologi, agama, struktur sosial. Hukum dalam perspektif ini berbentuk peraturan-peraturan lokal yang bersumber dari suatu kebiasaan masyarakat (customary law/folk law), termasuk pola di dalamnya mekanisme-mekanisme pengaturan dalam masyarakat (self regulation) yang juga berfungsi sebagai sarana pengendalian sosial (legal order).

Pluralisme hukum boleh dikatakan menjadi jawaban terhadap kekurangan yang ditemui pada cara pandang sistem hukum nasional di Indonesia yang cenderung sentralistik. Hal ini bisa dilihat dari beberapa kebijakan dan ketentuan peraturan perundang-undangan yang mengandung ide pluralisme hukum di dalamnya. Contoh klasik adalah UU Agraria yang secara jelas menyebut pengakuan terhadap hak masyarakat hukum adat dan tanah ulayat. Pada perkembangannya, tidak saja di tingkat nasional tetapi juga di tingkat daerah juga bermunculan peraturan daerah yang mencoba mengakui atau mengintegrasikan keberagaman hukum di tingkat lokal seiring dengan pemberlakuan otonomi daerah dan otonomi khusus. Sebagai contoh, maraknya pembentukan perda syariah di daerah, qanun di Aceh, dan pembentukan lembaga-lembaga adat yang diakui sebagai media penyelesaian sengketa adat.

Selintas lalu, situasi tersebut dapat diapresiasi sebagai sebuah terobosan pembaruan hukum dan upaya untuk mengakomodasi keragaman normatif yang ada di masyarakat. Namun demikian, dalam praktiknya dijumpai berbagai permasalahan yang membawa kita pada kondisi yang dilematis dan keadaan pluralisme hukum yang lemah sebagaimana pandangan Griffiths. 
Pasalnya, keberadaan hukum adat tersebut bergantung pada pengakuan hukum negara. Lebih jauh dari itu, apa yang disebut dengan hukum adat adalah konstruksi oleh hukum negara, dengan demikian hukum adat bukanlah hukum yang hidup dan dipercayai oleh masyarakat melainkan hukum adat yang dirumuskan oleh hukum negara. Kondisi ini tidak jauh berbeda dengan keberadaan lembaga adat tersebut, dimana hasil dari penyelesaian lembaga adat tidak jarang dimentahkan oleh lembaga peradilan atau lembaga ini nyaris tidak bertaji dalam menyelesaikan sengketa adat di lingkungan masyarakat adat sebab lembaga adat tersebut tidak mempunyai kapasitas mengeksekusi keputusan layaknya institusi peradilan. Lain halnya dengan Peraturan Daerah Syariah, yang mana di beberapa daerah, peraturan tersebut mengundang penolakan keras oleh masyarakat di daerah yang bersangkutan. Pasalnya, ketentuan dalam perda-perda demikian bertolak belakang dengan ketentuan undang-undang yang secara hierarki harus selaras, bahkan pada titik tertentu perda tersebut dinilai bertentangan dengan Hak Asasi Manusia.

Pluralisme hukum memang tidak seketika menyelesaikan permasalahan yang muncul dalam masyarakat. Akan tetapi, pluralisme hukum hadir untuk memberikan pemahaman yang baru kepada praktisi hukum, pembentuk hukum negara (para legislator) sertamasyarakatsecaraluas bahwa disamping hukum negara terdapat sistem-sistemhukum lain yang lebih dulu adadi masyarakat dan sistem hukum tersebut berinteraksi dengan hukum negara dan bahkan berkompetisi satu sama lain.

Disamping itu, pluralisme hukum memberikan penjelasan terhadap kenyataan adanya tertib sosial yang bukan bagian dari keteraturan hukum negara. Pandangan sentralistik berpendapat bahwa satu-satunya institusi yang berperan menciptakan keteraturan sosial adalah negara melalui hukum yang dibentuk dan ditetapkan oleh negara. Pada realitanya, banyak terdapat 'kekuatan lain' yang tidak berasal dari negara. Diantaranya, hukum adat, hukum agama, kebiasaan-kebiasaan, perjanjian-perjanjian perdagangan lintas bangsa dan sebagainya. Kekuatan-kekuatan tersebut sama-sama memiliki kemampuan mengatur tindakan-tindakan masyarakat yang terikat di dalamnya, bahkan terkadang anggota atau komunitas dalam 
masyarakat lebih memilih untuk mentaati aturan-aturan yang dibentuk oleh kelompoknya dibanding aturan hukum negara.

Bagi Griffiths, salah satu bentuk dari pluralisme hukum itu dibagi 2 macam, yaitu strong legal pluralism dan weak legal pluralism. Suatu kondisi dapat dikatakan strong legal pluralism jika masing-masing sistem hukum yang beragam itu otonom dan eksistensinya tidak tergantung kepada hukum negara. Jika keberadaan pluralisme hukum itu bergantung kepada pengakuan dari hukum negara maka kondisi seperti itu disebut dengan weak legal pluralism. Dengan kata lain, pluralisme hukum yang kuat karena ada situasi ketika antar berbagai sistem hukum melangsungkan interaksi yang saling tidak mendominasi alias sederajat. Individu atau kelompok yang hidup dalam lapangan atau wilayah sosial tertentu bebas memilih salah satu hukum dan bebas untuk mengkombinasikan berbagai sistem hukum dalam melangsungkan aktivitas keseharian atau untuk menyelesaikan sengketa. Pluralisme hukum yang lemah adalah salah satu sistem hukuim memiliki posisi superior di hadapan dengan sistem hukum lainnya. Individu atau kelompok lebih sering menggunakan salah satu sistem hukum karena tekanan.

Selanjutnya, berbagai konsep itu dikembangkan oleh Simarmata, pluralisme juga menemukan relasi antar berbagai sistem hukum tersebut, bisa saja berupa diffusi, kompetisi atau koorporatif. Misalnya hukum negara tidak selalu menyangkal hukum adat, namun juga mengakui dan mengakomodasi keberadaan hukum adat dan sebaliknya. Pluralisme hukum bukan hanya berkembang dalam hal wilayah atau objek kajian tetapi juga berkembang dengan cara lain, yakni mendetailkan atau menajamkan dirinya. Ada beberapa pemikiran seperti itu, di antaranya (1) strong legal pluralism and weak legal pluralism; (2) mapping of law; dan (3) critical legal pluralism.

Saat ini pendekatan pluralisme hukum semakin banyak digeluti oleh para ahli yang concern mengikuti perkembangan teori hukum, terutama di Indonesia sebagai masyarakat plural.28 Cara pandang pluralisme hukum berbeda dengan cara pandang legal centralism yang menjadikan masyarakat sebagai objek hukum. Masyarakat diposisikan sebagai subjek pasif yang 
siap menerima aturan hukum yang dirumuskan oleh penguasa dalam bentuk regulasi. Sementara dalam konsep pluralisme hukum, penguatan masyarakat sipil menjadi skala prioritas untuk berpartisipasi dalam membentuk sistem hukum yang plural

Pluralisme hukum mengandaikan adanya pilihan dalam penerapan hukum. Pilihan terhadap sebuah perilaku dipelajari, khususnya dalam kasus-kasus konflik. Jarang sekali hanya ada satu kemungkinan dalam hal yang berususan dengan konflik. Selain ada peradilan yang resmi oleh aparat pengadilan dari negara, biasanya ada pilihan yang sangat luas, seperti penengah dan juru runding

\section{PENUTUP}

Pluralisme hukum di Indonesia adalah pemahaman mengenai keberadaan mekanisme-mekanisme hukum yang berbeda yang ada di masyarakat di Indonesia. Pluralisme hukum di Indonesia ini berupa hukum Keperdataan, hukum Pidana, hukum Adat, hukum Tata Negara, hukum Administrasi Negara, hukum Internasional serta hukum-hukum lainnya. Secara sederhana, pluralisme hukum hadir sebagai kritikan terhadap sentralisme dan positivisme dalam penerapan hukum kepada rakyat.

Terdapat beberapa jalan dalam memahami pluralisme hukum. Pertama, pluralisme hukum menjelaskan relasi berbagai sistem hukum yang bekerja dalam masyarakat. Kedua, pluralisme hukum memetakan berbagai hukum yang ada dalam suatu bidang sosial. Ketiga, menjelaskan relasi, adaptasi, dan kompetisi antar sistem hukum. Ketiga, pluralisme hukum memperlihatkan pilihan warga memanfaatkan hukum tertentu ketika berkonflik. Dari tiga cara pandang tersebut dan masih banyak cara pandang lainnya, secara ringkas kita bisa katakan bahwa pluralisme hukum adalah kenyataan dalam kehidupan masyarakat.

Pluralisme hukum sebagai pendekatan atau kajian tidak lain adalah alat bantu bagi negara dalam proses pembentukan hukum dan pembangunan hukum yang lebih dekat dengan 
masyarakat ke depannya. Pendekatan ini bukanlah pendekatan final yang nihil kelemahan dan kritik atau bukanlah solusi yang serta merta menyelesaikan segala permasalahan hukum yang ada pada masyarakat hingga lapis terbawah. Kepastian hukum tetap menjadi prinsip penting yang perlu diperhatikan di tengah-tengah perspektif keberagaman sistem hukum tersebut. Inilah tantangan kajian pluralisme hukum saat ini dan di masa mendatang.

\section{DAFTAR PUSTAKA}

Gokma Toni Parlindungan S, Asas Nebis In Idem Dalam Putusan Hakim Dalam Perkara Poligami Di Pengadilan Negeri Pasaman Sebagai Ceriminan Ius Constitutum, Volume 2, Nomor 1, 2020.

Gokma Toni Parlindungan S, Pengisian Jabatan Perangkat Nagari Pemekaran Di Pasaman Barat Dalam Rangka Pelaksanaan Otonomi Daerah, Ensiklopedia Of Journal, Vol 1 No 2 Edisi 2 Januari 2019,

Harniwati, Peralihan Hak Ulayat Menurut Undang-Undang Nomor 18 Tahun 2004, Volume 1, Nomor 3, 2019.

Jasmir, Pengembalian Status Hukum Tanah Ulayat Atas Hak Guna Usaha, Soumatera Law Review, Volume 1, Nomor 1, 2018.

Jumrawarsi Jumrawarsi, Neviyarni Suhaili, Peran Seorang Guru Dalam Menciptakan Lingkungan Belajar Yang Kondusif, Ensikopedia Education Review, Vol 2, No 3 (2020): Volume 2 No.3 Desember 2020

Mia Siratni, Proses Perkawinan Menurut Hukum Adatdi Kepulauan Mentawai Di Sebelum Dan Sesudah Berlakunya Undang-Undang Nomor 1 Tahun 1974 Tentang Perkawinan, Ensiklopedia Of Journal, Vol 1 No 2 Edisi 2 Januari 2019,

Remincel, Dimensi Hukum Pelanggaran Kecelakaan Lalu Dan Angkutan Jalan Lintas Di Indonesia, Ensiklopedia Social Review, Volume 1, Nomor 2, 2019.

R Amin, B Nurdin, Konflik Perwakafan Tanah Muhammadiyah di Nagari Singkarak Kabupaten Solok Indonesia 2015-2019, Soumatera Law Review, Volume 3, Nomor 1, 2020. 